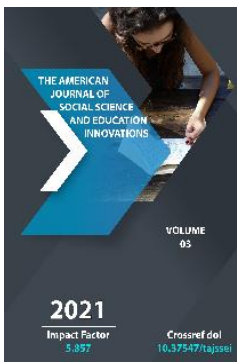

\title{
Developing Speech In Schoolchildren Innovative Methods
}

\author{
Eshmanov Gafur Juraevich \\ Tashkent Regional Center For Training And Professional Development Of The Staff Of Education \\ Of The People's Republic Of Uzbekistan Department Of Methods Of Language Teaching, \\ Uzbekistan
}

Journal Website:

http://usajournalshub.c

om/index,php/tajssei

Copyright: Original content from this work may be used under the terms of the creative commons attributes 4.0 licence.

\section{ABSTRACT}

Through speech, a person expresses his thoughts, feelings, and desires, and understands the thoughts, feelings, and desires of others. Speech will be oral and written. Spoken speech is a typical colloquial speech, which is more about tone and different gestures. It uses almost no complex grammatical devices or conjunctions. So it is important to teach students ways to express themselves from early school years. The following article looks into innovative methods of teaching school children speech.

\section{KEYWORDS}

Speech, vocal speech, written speech, active speech.

\section{INTRODUCTION}

1. Oral speech is a typical vocal speech, which is characterized by more tones 1 . And different gestures.
2. Written speech is a combination of letters and words on the basis of certain laws, punctuation, various separations: paragraphs, paragraphs. 
3. Internal speech is passive speech in which a person speaks within himself and does not require the participation of another person.

4. External speech is active speech that is directed at others and can be controlled.

Written speech is a more complex process that requires the reader to construct grammatically and semantically correct sentences, use each word correctly in its proper place, and learns spelling and punctuation requires adherence.

First of all, it should be noted that all subjects taught in school are focused on working on student speech. The science of the mother tongue is the most basic and important of these.

As a student's knowledge and outlook develop, so does his speech and thinking. A fluent, concise, and effective speech will delight the listener. One of the main tasks of the school is to teach its students to speak in this way.

The task of school teachers, first of all, the mother tongue teacher, is to prevent speech defects in students, to clean their speech from the influence of dialect, from the influence of various vulgar words, and to speak in accordance with the norms of literary language.

The main requirements for student speech are:

1. The suitability of speech to the conditions of speech.

Speech conditions are the conditions of the speaker and the listener at the time the speech is created. For example, if there is only one speaker and many listeners, the speaker is required to follow the pauses aloud and state the idea in a coherent and coherent manner.
The peculiarity of such a speech is reflected in the student's answers in the process of covering theoretical issues or homework, in the discovery of a particular topic in the classroom, in a meeting.

One of the most important components of a speech environment is that the speaker takes into account the level of the audience.

2. The content of the speech

A student's speech is meaningful only if it fits the context of the speech and describes the events he or she knows and is aware of, both orally and in writing. Evidence, opinions based on a student's personal observations or impressions, and feelings, attract the attention of others.

3. The speech should be logically correct, clear and consistent.

In speech, every thought is effective only if it is based on logic. It requires every student to look at things, to evaluate events, to evaluate each of them correctly, to construct a speech in a systematic and consistent way, to prove it. The student should be able to logically connect one idea with another when expressing an idea, be able to distinguish the main ideas related to the topic from the secondary ideas, and not allow back feedback.

\section{Rich and colorful speech}

The richness and diversity of speech, first of all, the lexical possibilities of the Uzbek language in the expression of ideas: from synonyms, synonyms and opposite meanings, figurative expressions and phrases, proverbs and sayings, figurative meaning is manifested in the extensive and appropriate use of artistic language tools such as words, analogies, adjectives. 
5. Grammatically correct speech.

The student must have the skills and abilities to connect words, phrases and sentences, to use adverbs and possessives appropriately, to adapt the possessive and the participle of a sentence.

\section{Tone of speech.}

Tone is a means of increasing the effectiveness of a student's speech. The student should read each piece of poetry or prose in a melodic manner, following the synthases and applying the logical emphasis correctly.

Reading is an important part of human life. Through reading, human beings, acquires knowledge of society from a blind person who does not know how to read it doesn't matter Primary school activities are taught in all subject classes is increased. But the way to teach reading is to develop a method of reading instructions turns out. General reading methods for young student's development, achievements in the field of private methodology are based on the achievements of existing sciences is formed. For example, it was studied in the old schools by the method of dry memorization while in modern schools; reading is done by the method of explanatory reading.

Explain the meaning of the words in the text by the method of memorization to explain, to retell what has been read, to read consciously in general has been completely ignored. They have more accurate pronunciation, with recitation great emphasis is placed on reading. Therefore, it is necessary to study in schools now is being read.

In the reading lessons, students learn about nature, society, people living in it, about their past, present lifestyle, celebrities, nature of the homeland: acquire knowledge about climate, resources, wildlife, and more Classroom reading includes the following tasks:

1. Improving reading skills. Good, accurate reading for students

Qualities: Developing accurate, fast, expressive reading skills.

2. It is necessary to instill in children a love for books, to use them to teach, that is, to think deeply, cultivating thoughtful libraries.

3. Expand students' knowledge of the environment, being, and scientific formation of elements of worldview.

4. Educate students in the spirit of ethics, aesthetics and diligence.

5. Develop students' speech and thinking.

6. Formation of elements of literary imagination.

A clear way to accomplish these tasks, the qualities of good reading skills and ways to improve them. True to the qualities of good reading skills, includes fast, conscious, and expressive reading, and they are interrelated in reading lessons these four reading qualities are inextricably linked.

Conscious reading is the key to good reading skills because the student fast short - if he does not understand what he is reading, such reading does not meet the requirements, leads to understanding. Reading correctly serves conscious reading.

Fast, accurate, and conscious reading is the foundation of expressive reading. Good reading mastering the qualities of successful mastery of all subjects in school is a condition.

Elementary students carefully synthesize the meaning of a text with correct pronunciation 
have difficulty doing. On the work to improve reading skills work should be done in conjunction with training.

Reading errors can occur for a variety of reasons:

1. Proper pronunciation between pronouncing a word and understanding its meaning tries to do and ignores the meaning.

2. Words are multi-syllable (when reading words with complex syllables), that is, make the mistake of saying that you read fast because of the complexity of the sound structure of the word they put.

3. Proper reading depends on the light, the font of the text, and the child's sense of sight depends. To ensure proper reading, the teacher should:

1. Before reading the text, read the words that are difficult to read, complex in structure, identify combinations and sentences, determine ways to work on them.

2. Identify words whose meaning is unclear.

3. The part of the text that is taught to good, average, and bad readers predefine.

4. Regular practice of reading under the supervision of a teacher or classmates makes. A place where students can make mistakes while the teacher is reading.

To eliminate error reading:

1. Divide complex words into syllables on a board or cardboard to write, to practice pre-reading them by tying them up and then reading them aloud.

2. A synonym, antonym, or use of a word in a sentence explanation

3. Using a letter stick. Letter to the distracted child, the sense of sight very useful for low students.
4. Warn the reader from the place where the error can be read.

5. Use of cross letters and cross syllables.

6. Create conditions for proper reading.

7. Use whispering and reading aloud.

There are two types of mistakes students make:

1. Mistakes that lead to misunderstandings. (Emphasis is incorrect thanks for reading)

2. Mistakes that prevent you from reading words.

Conscious reading reveals the content of the work, the ideological direction of the work, its symbols, reading comprehension of the role of artistic means is called conscious reading.

1. Breathe in and out properly.

2. Pronouncing sounds clearly, speaking burro.

3. Mastering the norms of literary pronunciation. This also applies to expressive speech.

Another condition for expressive reading is the loudness of the voice - low, pleasant, is able to change the punctuation according to the content of the work.

\section{REFERENCES}

1. Address of the President of the Republic of Uzbekistan to the Oliy Majlis. January 24, 2020. https://pv.uz/uz/newspapers.

2. Geraskin M.I. Pricing Models: Textbook. allowance / M.I. Geraskin, V.V. Egorova. Samara: Publishing house Samar. state aerospace. un-ta, 2014 --- $80 \mathrm{p}$.

3. Guseva N.V. Prices and pricing in the enterprise: textbook. manual / N. V. Guseva. - Samara: Samar. state tech. un-t, 2014 -- $160 \mathrm{p}$. 
4. I.V. Lipsits Pricing: textbook. -Practical. allowance. - M .: Yurayt Publishing House, $2011 .--399$ p.

5. Matkarimov K.Zh., Abdugafarov A. Modeling the formation of tariffs for transport services. Materials of the international scientific-practical conference MADI (TU) “Motor transport complex. Problems and Development Prospects ". Moscow 2000. pp. 303-304.

6. Alborov R.A., Livenskaya G.N. Management accounting of costs by centers of responsibility in industrial organizations: monograph. - Izhevsk: Publishing house "Udmurt University", 2013. - $108 \mathrm{p}$.

7. Issues of planning and factor analysis of economic indicators of transport operation // Ed. Mezonova N.I. and Nudelman R.N. Moscow: IKTP, 1983, 198 p. (Proceedings of ICTP. Issue 96).

8. Geraskin M.I. Pricing Models: Textbook. allowance / M.I. Geraskin, V.V. Egorova. Samara: Publishing house Samar. state aerospace. un-ta, 2014 .- 80 p. 